Article

\title{
Cardiovascular and Lung Involvement in Patients with Autoimmune Pancreatitis
}

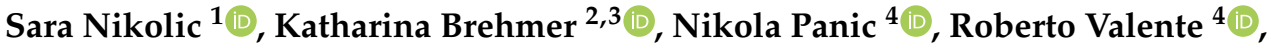 \\ J.-Matthias Löhr ${ }^{3,4}$ and Miroslav Vujasinovic $1,4, * \mathbb{D}$ \\ 1 Department of Medicine, Huddinge, Karolinska Institute, 14186 Stockholm, Sweden; sara.nikolic@ki.se \\ 2 Department of Radiology, Karolinska University Hospital, 14186 Stockholm, Sweden; \\ katharina.brehmer@sll.se \\ 3 Department of Clinical Science, Intervention, and Technology (CLINTEC), Karolinska Institute, \\ 14186 Stockholm, Sweden; matthias.lohr@ki.se \\ 4 Department for Digestive Diseases, Karolinska University Hospital, 14186 Stockholm, Sweden; \\ nikola.panicmail@gmail.com (N.P.); roberto.valente@sll.se (R.V.) \\ * Correspondence: miroslav.vujasinovic@sll.se; Tel.: +46-72469-49-38
}

Received: 31 December 2019; Accepted: 1 February 2020; Published: 3 February 2020

check for updates

\begin{abstract}
Introduction: Immunoglobulin G4-related disease (IgG4-RD) is a systemic immune-mediated disease characterised pathologically by the infiltration of IgG4-bearing plasma cells into the involved organs. Autoimmune pancreatitis (AIP) is a form of chronic pancreatitis with a heavy lymphocytic infiltration and two distinct histopathological subtypes, namely: lymphoplasmacytic sclerosing pancreatitis (AIP type 1) and idiopathic duct-centric pancreatitis (AIP type 2). Lung involvement and aortic involvement have been reported in $12 \%$ and $9 \%$ of patients with systemic IgG4-RD, respectively. In series including patients with AIP, both lung and aortic involvement were described in $2 \%$ of the patients. Most of the epidemiological data come from Japan, and there is a lack of information from Europe, especially the Scandinavian countries. Patients and methods: We performed a single-centre retrospective study on a prospectively collected cohort of patients diagnosed with AIP at the Department for Digestive Diseases at Karolinska University Hospital in Stockholm, Sweden, from 2004 to 2019. Demographic and clinical data were collected from the medical charts. Results: One hundred and thirty-three patients with AIP were analysed. Six patients were excluded because they lacked some of the clinical data relevant to the study. Demographic and clinical features of 127 patients were presented. There were 98 patients with AIP type 1-35 (35.7\%) female and $63(64.3 \%)$ male, with a mean age of $55.4 \pm 18.2$. Among them, $15(15.3 \%)$ patients had lung and/or cardiovascular involvement-11 (11.2\%) patients had lung involvement, $10(10.2 \%)$ patients had cardiovascular involvement (six patients had both). Most of them (67.0\%) had never smoked. The mean follow-up time of the patients with AIP type 1 was 49 months. Conclusions: Lung and/or cardiovascular involvement were diagnosed in $15(15.3 \%)$ patients in our historical cohort of patients with AIP type 1. Most of the lung involvement was presented in the form of nodular lesions in the lungs, non-specific infiltrates, "ground-glass" appearance with pleura thickening, and effusion. Aortic involvement was a major form of vascular involvement in patients with AIP, as in previous published studies on patients with IgG4-RD.
\end{abstract}

Keywords: autoimmune; pancreatitis; immunoglobulin G4; lung; cardiovascular

\section{Introduction}

Immunoglobulin G4-related disease (IgG4-RD) is a systemic immune-mediated disease characterised pathologically by the infiltration of IgG4-bearing plasma cells into the involved organs [1]. 
Autoimmune pancreatitis (AIP) is a particular form of chronic pancreatitis with a heavy lymphocytic infiltration and two distinct histopathological subtypes, namely: lymphoplasmacytic sclerosing pancreatitis (LPSP; AIP type 1) and idiopathic duct-centric pancreatitis (IDCP; AIP type 2) [2].

AIP type 1 is considered to be a part of IgG4-RD, but the IgG4 values in the serum are not necessarily elevated in all of the patients. According to the International Consensus Diagnostic Criteria (ICDC), the diagnosis of AIP is based on the presence of one or more of the following factors: pancreatic parenchyma and pancreatic duct imaging, serum IgG4 level, other organ involvement (OOI), histology of the pancreas, and response to steroid treatment [3].

IgG4-RD is a relatively new clinical entity, and there is no specific definition of its epidemiology because of the multiple knowledge gaps and the fact that many physicians are unfamiliar with the diagnosis [4]. According to our recently published single-centre data, OOI was present in $84 \%$ of patients with AIP [5], which is higher when compared with other European studies, which vary from $47 \%$ to $61 \%$ [6-9].

Asthma and autoimmune diseases are a result of a dysregulated immune system [10], and pulmonary involvement (including lung, pleura, and mediastinum) has been reported in $12 \%$ of patients with systemic IgG4-RD presentations, and in $2 \%$ of patients in pancreatobiliary series [4]. Aortic involvement has been reported in $9 \%$ of patients with systemic IgG4-RD presentations and in $2 \%$ of patients in pancreatobiliary series [4]. Most of the epidemiological data comes from Japan, and there is a lack of information from Europe, especially the Scandinavian countries.

\section{Patients and Methods}

We performed a single-centre retrospective study on a prospectively collected cohort of patients with AIP diagnosed at the Department for Digestive Diseases at Karolinska University Hospital in Stockholm, Sweden, from 1 January 2004 to 1 December 2019.

Consecutive patients with a diagnosis of AIP according to the ICDC were included in the study. A retrospective analysis and diagnosis according to the ICDC criteria were performed for patients diagnosed in the period before the publication of ICDC [3]. The re-assessment of the ICDC classification was done by two independent senior investigators.

The following demographic and clinical data were collected from the medical records: gender, age, type of AIP (definite or probable-type 1, type 2, and non-otherwise specified (AIP NOS)), follow-up period (defined as the period between date of AIP diagnosis and the last contact with the patients), treatment of AIP, time of lung/cardiovascular involvement, type of lung/cardiovascular involvement (single nodular lesion, multiple nodular lesions, vasculitis, aortic involvement, cardiac involvement), duration of lung/cardiovascular involvement (defined as the period from the lung/cardiovascular disease diagnosis and last contact with the patient), treatment of lung/cardiovascular disease, other organ involvement (other than pancreas, lungs, heart, and vessels), smoking status (described as never, former, and active smokers), and clinical status at the last contact with patients regarding pancreas and lung disease (stable disease or relapse).

\subsection{Ethics}

The study was approved by the Clinic Ethical Committee in Stockholm (no. 2016/1571-31) and adheres to the latest version of the Declaration of Helsinki.

\subsection{Statistics}

A comparison of the data between the groups was evaluated using the $t$-test, chi-square, or Fisher's test, where appropriate. A statistical analysis was performed using Stata software version 12 (Stata Corp, College Station, TX, USA). 


\section{Results}

One hundred and thirty-three patients with AIP were analysed (Figure 1 and Table 1). Six patients were excluded, as they lacked some of the clinical data relevant to the study. The demographic and clinical features of 127 patients are presented in Table 1.

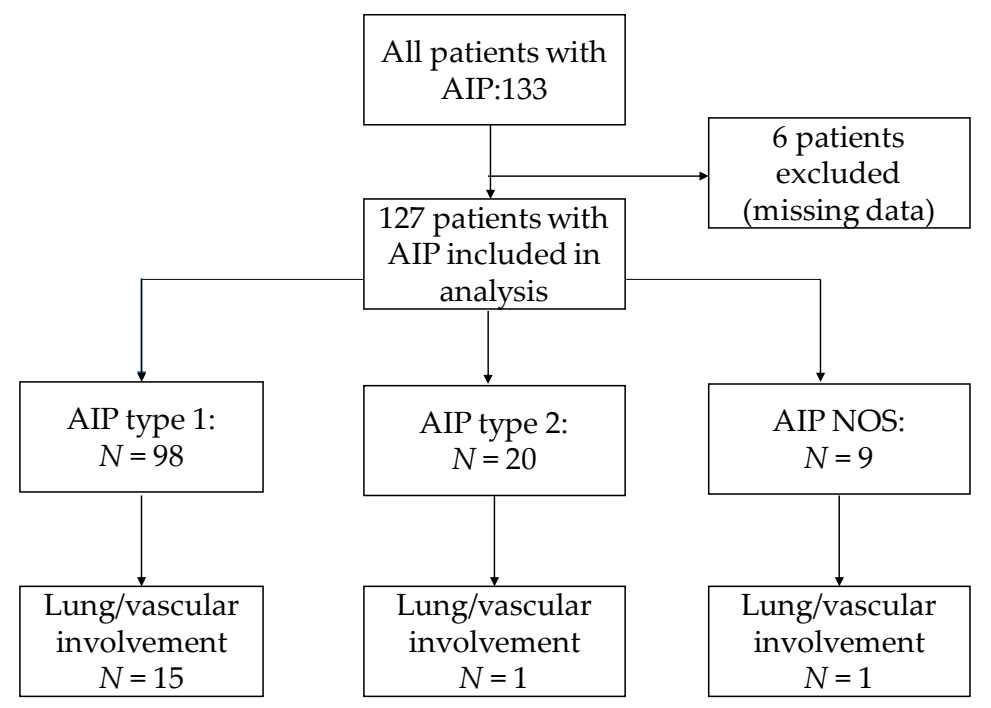

Figure 1. Flow chart of the included patients.

Table 1. Demographic and clinical characteristics of patients.

\begin{tabular}{cccc}
\hline Parameter & $\begin{array}{c}\text { AIP with Vascular/Lung } \\
\text { Involvement }\end{array}$ & $\begin{array}{c}\text { AIP without Vascular/Lung } \\
\text { Involvement }\end{array}$ & $p$ \\
\hline Number $(\%)$ & $17(13.4 \%)$ & $110(86.1 \%)$ & 0.457 \\
\hline AIP type & $15(88.2 \%)$ & $83(75.4 \%)$ & \\
Type 1 & $1(5.9 \%)$ & $8(17.3 \%)$ & 0.960 \\
Type 2 & $1(5.9 \%)$ & $46.3 \%)$ & 0.083 \\
\hline Not otherwise specified & $7(41.2 \%)$ & $64(58.2 \%)$ & 0.223 \\
\hline Gender & $10(58.8 \%)$ & $51.00 \pm 19.58$ & $45.88 \pm 44.51$ \\
\hline Male & $59.76 \pm 16.36$ & & \\
\hline Age * & $60.43 \pm 52.60$ & & \\
\hline Follow-up ** (months) &
\end{tabular}

AIP-autoimmune pancreatitis; AIP-NOS-autoimmune pancreatitis not otherwise specified; * age at the time of AIP $\mathrm{dg} ;{ }^{* *}$ period between AIP dg and time of last contact with patient;

There were 98 patients with AIP type 1-35 (35.7\%) female and $63(64.3 \%)$ male, and the mean age was $55.4 \pm 18.2$. Among them, $15(15.3 \%)$ patients had lung and/or cardiovascular involvement-11 $(11.2 \%)$ patients with lung involvement, $10(10.2 \%)$ patients with cardiovascular involvement (6 patients had both). Most of them (67.0\%) had never smoked. The mean follow-up period of the patients with AIP type 1 was 49 months.

Most of the lung involvement in the patients with AIP type 1 (Table 2) was presented in the form of nodular lesions in lungs (54.4\%), non-specific infiltrates (36.4\%), "ground-glass" appearance $(18.2 \%)$, pleura thickening $(18.2 \%)$, pleural effusion $(18.2 \%)$, and mediastinal lymph nodes enlargement $(9.1 \%)$. In $36.4 \%$ of the patients, more than one form of lung involvement was presented. In seven patients (63.6\%), lung involvement occurred after the diagnosis of AIP type 1 ; in three patients $(27.3 \%)$, at the time of AIP diagnosis, and in one (9.1\%) patient, before the diagnosis of AIP. One (9.1\%) patient had a relapse of lung involvement (Figure 2). 
Table 2. Demographic and clinical features of patients with AIP type 1 and lung involvement.

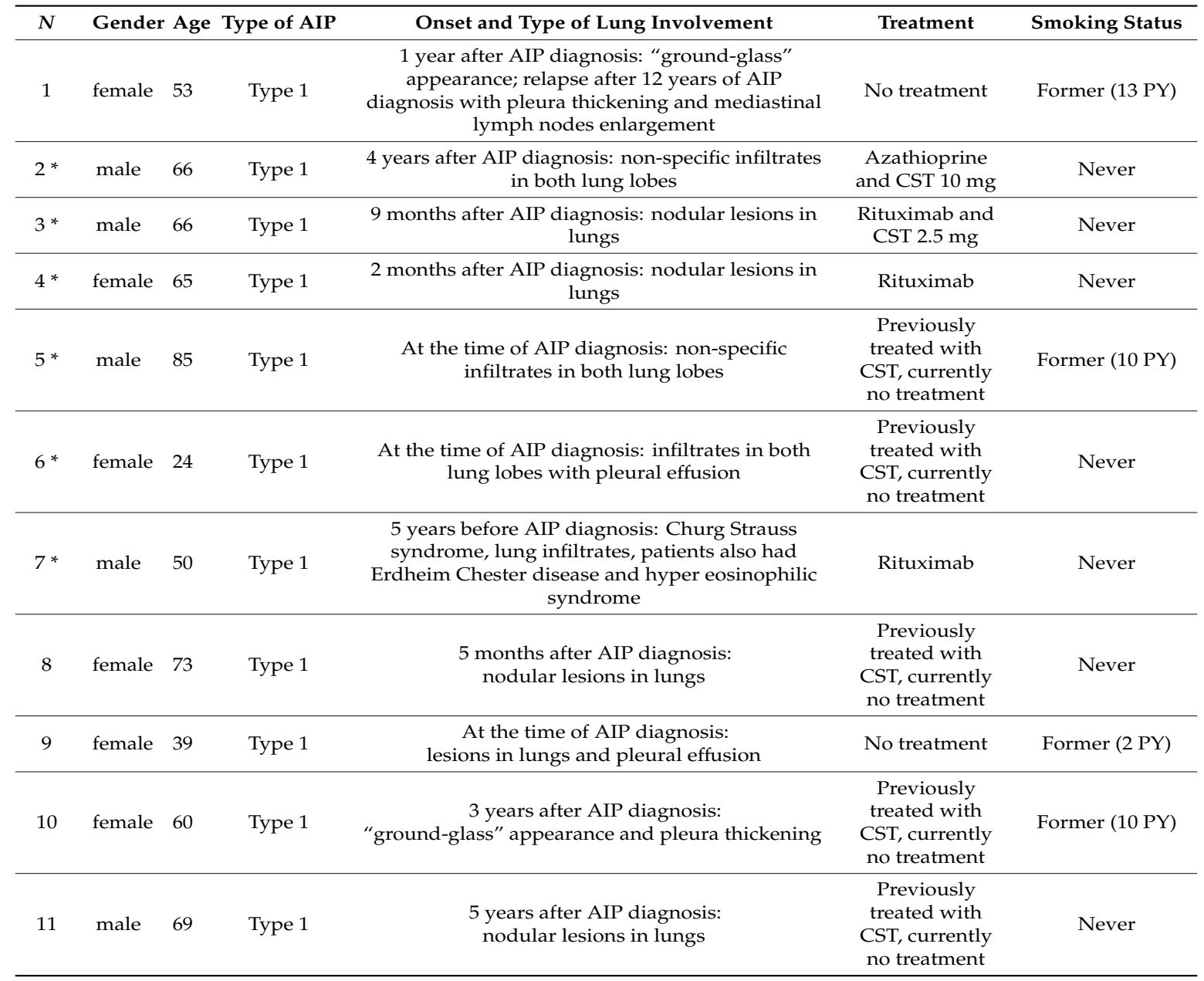

AIP-autoimmune pancreatitis; * patients also in Table 3; PY-pack-years of smoking; CST-corticosteroids; age-age of patients at the time of AIP diagnosis.

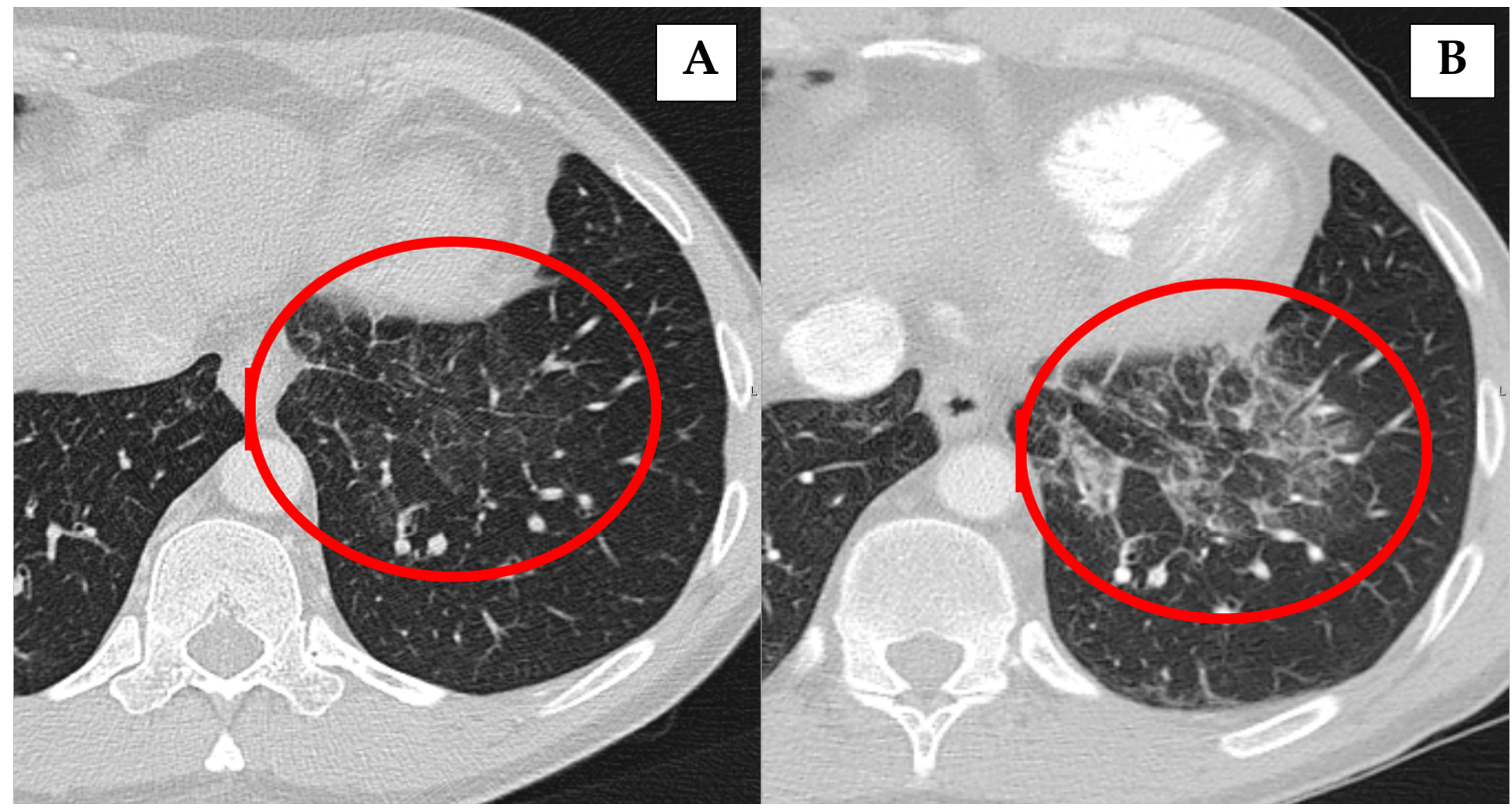

Figure 2. Inflammatory changes in the lungs (B) that decrease in size and disappear after corticosteroid treatment (A). 
Table 3. Demographic and clinical features of patients with AIP type 1 and cardiovascular involvement.

\begin{tabular}{|c|c|c|c|c|c|c|}
\hline$N$ & Gender & Age & Type of AIP & $\begin{array}{l}\text { Onset and Type } \\
\text { of Vasculitis }\end{array}$ & Treatment & Smoking Status \\
\hline 1 & male & 75 & Type 1 & $\begin{array}{c}4 \text { years after AIP diagnosis: } \\
\text { asymmetric thickening of aorta } \\
\text { wall (up till } 5 \mathrm{~mm} \text { ) in infrarenal } \\
\text { part of aorta }\end{array}$ & $\begin{array}{l}\text { Rituximab and } \\
\text { CST } 10 \mathrm{mg}\end{array}$ & Former (30 PY) \\
\hline $2 *$ & male & 66 & Type 1 & $\begin{array}{l}4 \text { years after AIP diagnosis: } \\
\text { thickening of aorta wall over } \\
\text { the bifurcation }\end{array}$ & $\begin{array}{l}\text { Azathioprine and } \\
\text { CST } 10 \mathrm{mg}\end{array}$ & Never \\
\hline 3 & male & 57 & Type 1 & $\begin{array}{l}\text { At the time of AIP diagnosis: } \\
\text { circumferential thickening of } \\
\text { aorta wall }\end{array}$ & Rituximab & Never \\
\hline $4^{*}$ & male & 66 & Type 1 & $\begin{array}{c}\text { GPA } 9 \text { months after AIP: } \\
\text { diagnosis with lung and bowel } \\
\text { involvement }\end{array}$ & $\begin{array}{l}\text { Rituximab and } \\
\text { CST } 2.5 \mathrm{mg}\end{array}$ & Never \\
\hline $5 *$ & female & 65 & Type 1 & $\begin{array}{l}\text { GPA } 2 \text { months after AIP: } \\
\text { diagnosis with lung } \\
\text { involvement }\end{array}$ & Rituximab & Never \\
\hline 6 & male & 65 & Type 1 & $\begin{array}{l}1 \text { year after AIP diagnosis: } \\
\text { mild thickening in infrarenal } \\
\text { part of aorta }\end{array}$ & $\begin{array}{l}\text { No treatment so } \\
\text { far }\end{array}$ & Never \\
\hline 7 & male & 68 & Type 1 & $\begin{array}{l}3 \text { months after AIP diagnosis: } \\
\text { vasculitis in form of skin } \\
\text { changes }\end{array}$ & $\begin{array}{l}\text { Previously treated } \\
\text { with CST and now } \\
\text { hematologic } \\
\text { treatment with } \\
\text { lenalidomide } \\
\text { (multiple } \\
\text { myeloma) }\end{array}$ & Former (8 PY) \\
\hline $8^{*}$ & male & 85 & Type 1 & $\begin{array}{l}\text { At the time of AIP diagnosis: } \\
\text { imaging signs of periaortitis }\end{array}$ & $\begin{array}{l}\text { Previously treated } \\
\text { with CST, } \\
\text { currently no } \\
\text { treatment }\end{array}$ & Former (10 PY) \\
\hline $9 *$ & female & 24 & Type 1 & $\begin{array}{l}\text { At the time of AIP diagnosis: } \\
\text { eosinophilic myocarditis }\end{array}$ & $\begin{array}{l}\text { Previously with } \\
\text { CST, currently no } \\
\text { treatment }\end{array}$ & Never \\
\hline $10 *$ & male & 50 & Type 1 & $\begin{array}{l}5 \text { years before AIP diagnosis: } \\
\text { Churg Strauss syndrome, } \\
\text { pericarditis and eosinophilic } \\
\text { myocarditis, patients also had } \\
\text { Erdheim Chester disease and } \\
\text { hyper eosinophilic syndrome }\end{array}$ & Rituximab & Never \\
\hline
\end{tabular}

Asymmetric thickening of aorta wall was the most common (60\%) form of vascular involvement (Table 3). Granulomatosis with polyangiitis (GPA) was present in two (20\%) patients, Churg Strauss in one $(10 \%)$ patient, and vasculitis in the form of skin changes in one $(10 \%)$ patient. Cardiac involvement was seen in two $(20 \%)$ patients in the form of eosinophilic myocarditis.

The distribution of the demographic and clinical features of the patients included in relation to the presence of lung/cardiovascular involvement showed no significant difference regarding AIP type, gender, age, treatment, or smoking (Table 1). OOI (Sjögren disease, sialadenitis, dacryoadenitis, and kidney involvement) was more common in patients with lung/cardiovascular involvement.

\section{Discussion}

Lung and/or cardiovascular involvement were diagnosed in 15 (15.3\%) out of 98 patients with AIP type 1 . 
Most of the lung involvement presented in the form of nodular lesions in the lungs, non-specific infiltrates, "ground-glass" appearance with pleura thickening, and effusion (Table 2). The pulmonary manifestation of IgG4-RD according to anatomic compartments can generally be categorised as parenchyma (nodules, masses, and interstitial lung disease), airway (stenosis, endobronchial mass, and bronchospastic disease), vasculature (vasculitis and pulmonary hypertension), mediastinum (lymphadenopathy and fibrosing mediastinitis), and pleural (thickening mass, and effusion) involvement [11].

In a cross-sectional study of 114 patients, thoracic involvement (lung and pleura) was found in $16(14 \%)$ patients [12]. Zen and colleagues reported 21 patients with IgG4-related lung and pleural involvement, and of these patients, $47 \%$ had subjective pulmonary symptoms (the others were asymptomatic and diagnosed on routine work-up) [13]. In another report from the same group, nine cases of inflammatory pseudotumor of the lungs were reported (two out of nine were symptomatic) [14]. Taniguchi and colleagues described a case of interstitial pneumonia associated with AIP [15], and Yamashita and colleagues reported three cases of interstitial lung disease with a common histology and abundant IgG4-positive cell infiltration [16]. Matsui and colleagues reported 18 patients with lymphadenopathy, thickening of the bronchial wall, nodules, subpleural, and peribronchovascular consolidation [17].

The aortic involvement in our group of patients was a major form of vascular involvement in the patients with AIP, as in previous published studies on patients with IgG4-RD [4]. Other vascular involvement has been rarely reported $[4,18]$. In our patients, no aortic dilation or aneurysms were diagnosed.

Granulomatosis with polyangiitis (GPA), formerly known as Wegener's granulomatosis, and Churg-Strauss was diagnosed in four patients and successfully treated with rituximab (Tables 2 and 3).

In a recently published retrospective analysis, Yoo and colleagues investigated whether elevated serum IgG4 at the time of diagnosis of microscopic polyangiitis (MPA) and GPA may be associated with concurrent IgG4-related disease (IgG4-RD) in immunosuppressive drug-naïve patients [19]. The mean serum IgG did not vary between the groups, and among the 46 patients, they could not find patients who could be classified as IgG4-RD. Although GPA is not part of IgG4-RD, it is worth mentioning that in the context of OOI, it is an important differential diagnosis (which is why it was included in our analysis). It is important to exclude other diseases from the same group (diseases with multisystem involvement and diseases with pulmonary inflammation and increased IgG4 plasma cells), such as connective tissue diseases with lung involvement, sarcoidosis, eosinophilic granulomatous with polyangiitis (Churg-Strauss), multicentric Castelman's disease, and Rosai-Dorfman disease [11]. The results of the most relevant studies are presented in Tables 4 and 5 .

In 18 out of 127 patients (14.2\%) with AIP, we diagnosed asthma alone or in combination with other clinical conditions (Table 1). Asthma is traditionally considered as being a heterogeneous respiratory condition clinically characterised by airway inflammation, reversible airflow obstruction, and airway hyperresponsiveness, but the recent discovery of novel pathogenic effector cells has led to theories of common underlying pathophysiological pathways [10]. Corticosteroids (CST) are the cornerstone of the treatment of both AIP and the inflammatory component of asthma, just like all other autoimmune diseases. The presence of autoantibodies in the lungs could be one of the mechanisms that contribute to the observed steroid sub-sensitivity in severe asthmatics [10,25]. Ito and colleagues reported three cases of bronchial asthma preceding IgG4-related autoimmune pancreatitis by three months to 30 years [26].

In a nationwide study conducted in Sweden, standardised incidence ratios (SIRs) were calculated for the subsequent autoimmune diseases in 4006 patients who were hospitalised for an autoimmune condition after the last hospitalisation for asthma [27]. The SIRs were increased for 11 subsequent autoimmune conditions diagnosed at least five years following asthma diagnosis. As a result of the relatively low number of included patients and limited data, it is not possible to draw any strong 
conclusions regarding a possible association between asthma and AIP. However, the presence of asthma in $14.2 \%$ of our patients could be a good starting point for further studies on this topic. Of course, it is not possible to exclude the possible interaction with environmental factors.

Table 4. Studies on vascular involvement in patients with IgG4-related diseases (IgG4-RD).

\begin{tabular}{|c|c|c|c|c|c|}
\hline Author & Year & Country & Patients & $\begin{array}{l}\text { Age/ } \\
\text { Gender }\end{array}$ & Vascular Involvement \\
\hline Ozawa [20] & 2017 & Japan & $\begin{array}{l}179 \text { patients with } \\
\text { IgG4-RD }\end{array}$ & $\begin{array}{c}67 \text { years/ } \\
73.2 \% \text { male }\end{array}$ & $\begin{array}{c}\text { Periaortitis/periarteritis: } \\
36.3 \%\end{array}$ \\
\hline Perugino [21] & 2015 & USA & $\begin{array}{l}160 \text { patients with } \\
\text { IgG4-RD }\end{array}$ & $\begin{array}{l}54.6 \text { years/ } \\
78 \% \text { male }\end{array}$ & $\begin{array}{c}\text { Large-vessel involvement: } \\
22.5 \%\end{array}$ \\
\hline Yabusaki [22] & 2017 & Japan & $\begin{array}{l}37 \text { patients with } \\
\text { IgG4-RD }\end{array}$ & $\begin{array}{c}68 \text { years/ } \\
64.9 \% \text { male }\end{array}$ & Aortitis: $41 \%$ \\
\hline Inoue [23] & 2015 & $\begin{array}{c}\text { Japan } \\
\text { (8 centres) }\end{array}$ & $\begin{array}{l}235 \text { patients with } \\
\text { IgG4-RD }\end{array}$ & $\begin{array}{c}67 \text { years/ } \\
80.4 \% \text { male }\end{array}$ & Aorta involvement: $8.5 \%$ \\
\hline Brito-Zeron [4] & 2014 & $\begin{array}{c}\text { Review (North } \\
\text { America, Europe } \\
\text { and Asia) }\end{array}$ & $\begin{array}{l}3482 \text { reported cases } \\
\text { of IgG4-RD }\end{array}$ & Not reported & $\begin{array}{c}\text { Aortic involvement: } \\
35 / 375(9 \%) \text { in systemic } \\
\text { series } \\
5 / 313(2 \%) \text { in } \\
\text { pancreatobiliary series } \\
36 / 268(13 \%) \text { in other series }\end{array}$ \\
\hline $\begin{array}{l}\text { Presenting } \\
\text { study }\end{array}$ & 2019 & Sweden & $\begin{array}{l}98 \text { patients with } \\
\text { autoimmune } \\
\text { pancreatitis type } 1\end{array}$ & $\begin{array}{c}55.4 \text { years } / 60.9 \% \\
\text { male }\end{array}$ & $10.2 \%$ \\
\hline
\end{tabular}

Table 5. Studies on lung involvement in patients with IgG4-related diseases (IgG4-RD).

\begin{tabular}{|c|c|c|c|c|c|}
\hline Author & Year & Country & Patients & $\begin{array}{c}\text { Age/ } \\
\text { Gender }\end{array}$ & Lung Involvement \\
\hline Wallace & 2015 & USA & $\begin{array}{l}125 \text { patients with } \\
\text { IgG4-RD }\end{array}$ & $\begin{array}{l}50.3 \text { years/ } \\
61 \% \text { male }\end{array}$ & $17.6 \%$ \\
\hline Zen [12] & 2010 & Japan & $\begin{array}{l}114 \text { patients with } \\
\text { IgG4-RD }\end{array}$ & $\begin{array}{c}65 \text { years/ } \\
76.3 \% \text { male }\end{array}$ & $9.6 \%$ \\
\hline Brito-Zeron [4] & 2014 & $\begin{array}{c}\text { Review (North } \\
\text { America, Europe } \\
\text { and Asia) }\end{array}$ & $\begin{array}{c}3482 \text { reported cases } \\
\text { of IgG4-RD }\end{array}$ & Not reported & $\begin{array}{c}75 / 620(12 \%) \text { in systemic } \\
\text { series } \\
\text { 18/237 }(8 \%) \text { in glandular } \\
\text { series } \\
6 / 313(2 \%) \text { in } \\
\text { pancreatobiliary series } \\
75 / 253(30 \%) \text { in other series }\end{array}$ \\
\hline $\begin{array}{l}\text { Fernandez-Codina } \\
\text { [24] }\end{array}$ & 2015 & $\begin{array}{c}\text { Spain } \\
(14 \text { centres })\end{array}$ & $\begin{array}{l}55 \text { patients with } \\
\text { IgG4-RD }\end{array}$ & $\begin{array}{c}53 \text { years/ } \\
69.1 \% \text { male }\end{array}$ & $9 \%$ \\
\hline Inoue [23] & 2015 & $\begin{array}{c}\text { Japan } \\
\text { (8 centres) }\end{array}$ & $\begin{array}{l}235 \text { patients with } \\
\text { IgG4-RD }\end{array}$ & $\begin{array}{c}67 \text { years/ } \\
80.4 \% \text { male }\end{array}$ & $5.5 \%$ \\
\hline Ogoshi & 2015 & Japan & $\begin{array}{l}35 \text { patients with } \\
\text { autoimmune } \\
\text { pancreatitis }\end{array}$ & $\begin{array}{c}67 \text { years/ } \\
68.6 \% \text { male }\end{array}$ & $40 \%$ \\
\hline $\begin{array}{l}\text { Presenting } \\
\text { study }\end{array}$ & 2019 & Sweden & $\begin{array}{l}98 \text { patients with } \\
\text { autoimmune } \\
\text { pancreatitis type } 1\end{array}$ & $\begin{array}{c}55.4 \text { years } / 60.9 \% \\
\text { male }\end{array}$ & $11.2 \%$ \\
\hline
\end{tabular}

De Buy Wenniger and colleagues hypothesised that professions traditionally considered as "blue collar", as well as chronic occupational antigen exposure, could play a crucial pathogenic role for the mainly elderly male IgG4-RD patients in a Dutch cohort of 25 patients (IgG4-associated cholangitis and AIP) [28]. However, an analysis of the job history of our group of patients could not confirm the Dutch hypothesis, as only $29.5 \%$ of patients belonged to "blue collar" professions, and there was no significant difference between patients with and without lung/cardiovascular involvement. 
Another interesting finding was the fact that lung/cardiovascular involvement was presented not only in patients with AIP type 1 (which is considered to be part of IgG-RD), but also in patients with AIP type 2 (one patient) and AIP-NOS (one patient), which are not associated with IgG4-RD.

In most of our patients, lung involvement and vascular involvement were diagnosed with imaging as part of the AIP work-up, and none of the patients with nodular lesions were symptomatic (except for patients with GPA and Churg-Strauss syndrome who were treated via rheumatologists). Patients with AIP responded excellently to initial CST (Figures 2 and 3), but relapses of the disease are common and other types of treatment are necessary (Table 1).

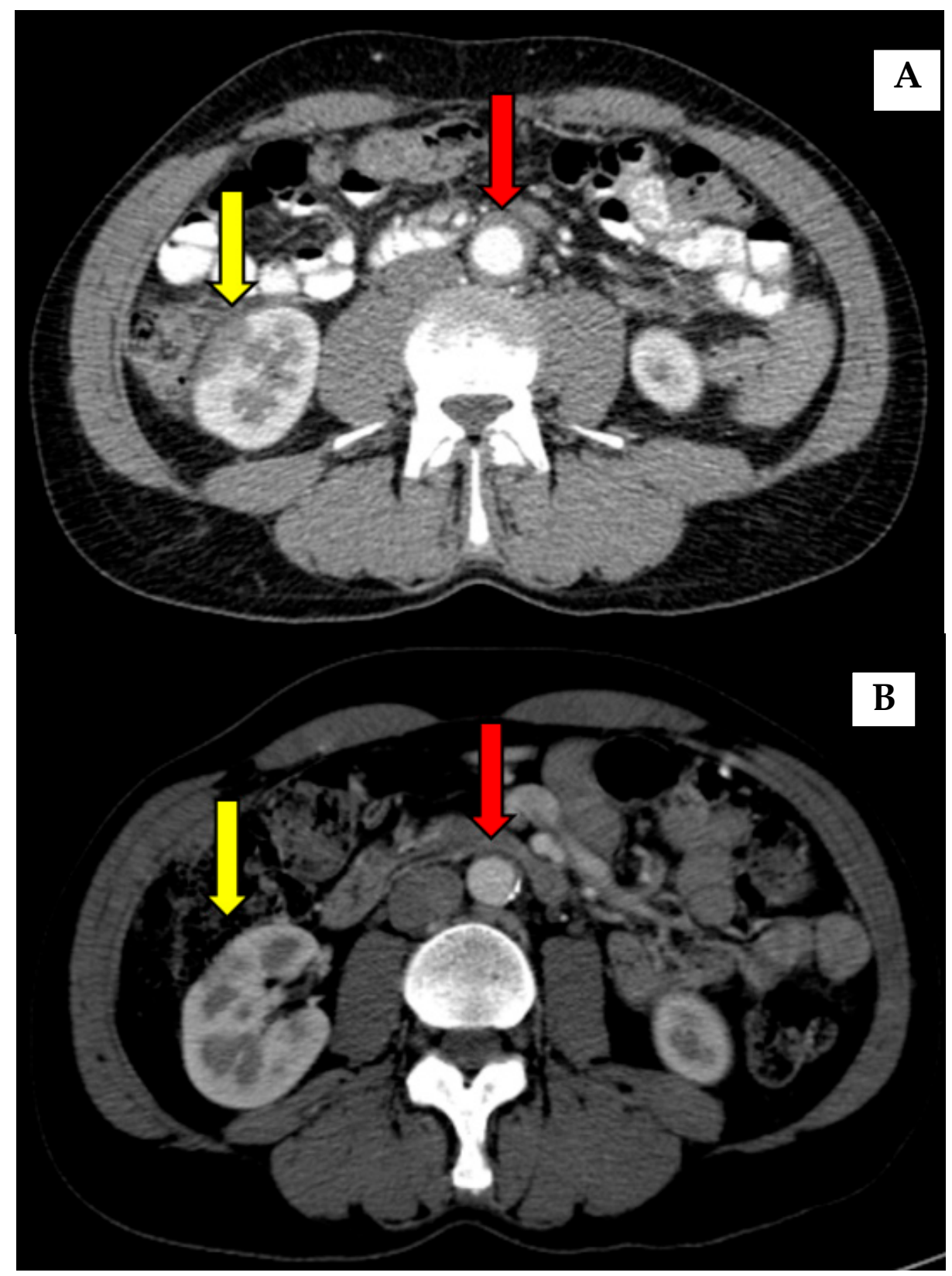

Figure 3. Inflammatory changes in aorta-thickening of aorta wall before (A) and after (B) corticosteroid treatment (red arrow). An improvement of kidney involvement after the treatment was also seen (yellow arrow).

Heterogeneous groups of patients with lung/cardiovascular involvement present a weakness in the presented study. The authors are aware that GPA and asthma cannot be considered as being a 
direct part of IgG4-RD, but the purpose of the study was to present all patients with all kinds of lung and cardiovascular involvement, as this is extremely important from a clinical point of view, especially for gastroenterologists and surgeons, who meet these patients and must be aware of possible other organ involvement and its clinical importance.

It is still the case that most of the data on this topic come from Japan, despite the fact that IgG4-RD has been described in nearly all racial and ethnic groups [4]. Further studies on different aspects of IgG-RD and AIP should be strongly encouraged in order to increase the awareness of the disease among physicians, and from this point of view, our results show the significance of the study and that it constitutes an important contribution to an improved understanding of the natural course of AIP.

\section{Conclusions}

Lung and/or cardiovascular involvement was diagnosed in 15 (15.3\%) patients in our historical cohort of patients with AIP type 1. Most of the lung involvement was presented in the form of nodular lesions in the lungs, non-specific infiltrates, "ground-glass" appearance with pleura thickening, and effusion. Aortic involvement was a major form of vascular involvement in patients in AIP, as in previous published studies on patients with IgG4-RD. From a clinical point of view, increasing awareness of AIP and other organ involvement is necessary for all types of clinicians.

Author Contributions: Conceptualization, S.N. and M.V.; methodology, M.V., J.-M.L.; software and formal analysis, S.N., K.B., N.P.; investigation, S.N., K.B., M.V.; resources, M.V., K.B., J.-M.L.; data curation, S.N., K.B., M.V.; writing-original draft preparation, M.V.; writing — review and editing, all authors; visualization, all authors.; supervision, all authors; project administration, S.N., M.V., J.-M.L. All authors have read and agreed to the published version of the manuscript.

Funding: This research received no external funding.

Conflicts of Interest: The authors declare no conflict of interest.

\section{References}

1. Stone, J.H.; Zen, Y.; Deshpande, V. IgG4-related disease. N. Engl. J. Med. 2012, 366, 539-551. [CrossRef] [PubMed]

2. Klöppel, G.; Luttges, J.; Löhr, M.; Zamboni, G.; Longnecker, D. Autoimmune pancreatitis: Pathological, clinical, and immunological features. Pancreas 2003, 27, 14-19. [CrossRef] [PubMed]

3. Shimosegawa, T.; Chari, S.T.; Frulloni, L.; Kamisawa, T.; Kawa, S.; Mino-Kenudson, M. International consensus diagnostic criteria for autoimmune pancreatitis: Guidelines of the International Association of Pancreatology. Pancreas 2011, 40, 352-358. [CrossRef] [PubMed]

4. Brito-Zeron, P.; Ramos-Casals, M.; Bosch, X.; Stone, J.H. The clinical spectrum of IgG4-related disease. Autoimmun. Rev. 2014, 13, 1203-1210. [CrossRef] [PubMed]

5. Vujasinovic, M.; Valente, R.; Maier, P.; von Beckerath, V.; Haas, S.L.; Arnelo, U. Diagnosis, treatment and long-term outcome of autoimmune pancreatitis in Sweden. Pancreatology 2018, 18, 900-904. [CrossRef] [PubMed]

6. Frulloni, L.; Scattolini, C.; Falconi, M.; Zamboni, G.; Capelli, P.; Manfredi, R. Autoimmune pancreatitis: Differences between the focal and diffuse forms in 87 patients. Am. J. Gastroenterol. 2009, 104, 2288-2294. [CrossRef]

7. Czako, L.; Gyokeres, T.; Topa, L.; Sahin, P.; Takacs, T.; Vincze, A. Autoimmune pancreatitis in Hungary: A multicenter nationwide study. Pancreatology 2011, 11, 261-267. [CrossRef]

8. Church, N.I.; Pereira, S.P.; Deheragoda, M.G.; Sandanayake, N.; Amin, Z.; Lees, W.R. Autoimmune pancreatitis: Clinical and radiological features and objective response to steroid therapy in a UK series. Am. J. Gastroenterol. 2007, 102, 2417-2425. [CrossRef]

9. Lopez-Serrano, A.; Crespo, J.; Pascual, I.; Salord, S.; Bolado, F.; Del-Pozo-Garcia, A.J. Diagnosis, treatment and long-term outcomes of autoimmune pancreatitis in Spain based on the International Consensus Diagnostic Criteria: A multi-centre study. Pancreatology 2016, 16, 382-390. [CrossRef]

10. Mukherjee, M.; Nair, P. Autoimmune Responses in Severe Asthma. Allergy Asthma Immunol. Res. 2018, 10, 428-447. [CrossRef] 
11. Ryu, J.H.; Yi, E.S. Immunoglobulin G4-Related Disease and the Lung. Clin. Chest Med. 2016, 37, 569-578. [CrossRef] [PubMed]

12. Zen, Y.; Nakanuma, Y. IgG4-related disease: A cross-sectional study of 114 cases. Am. J. Surg. Pathol. 2010, 34, 1812-1819. [CrossRef] [PubMed]

13. Zen, Y.; Inoue, D.; Kitao, A.; Onodera, M.; Abo, H.; Miyayama, S. IgG4-related lung and pleural disease: A clinicopathologic study of 21 cases. Am. J. Surg. Pathol. 2009, 33, 1886-1893. [CrossRef] [PubMed]

14. Zen, Y.; Kitagawa, S.; Minato, H.; Kurumaya, H.; Katayanagi, K.; Masuda, S. IgG4-positive plasma cells in inflammatory pseudotumor (plasma cell granuloma) of the lung. Hum. Pathol. 2005, 36, 710-717. [CrossRef] [PubMed]

15. Taniguchi, T.; Ko, M.; Seko, S.; Nishida, O.; Inoue, F.; Kobayashi, H. Interstitial pneumonia associated with autoimmune pancreatitis. Gut 2004, 53, 770.

16. Yamashita, K.; Haga, H.; Kobashi, Y.; Miyagawa-Hayashino, A.; Yoshizawa, A.; Manabe, T. Lung involvement in IgG4-related lymphoplasmacytic vasculitis and interstitial fibrosis: Report of 3 cases and review of the literature. Am. J. Surg. Pathol. 2008, 32, 1620-1626. [CrossRef]

17. Matsui, S.; Hebisawa, A.; Sakai, F.; Yamamoto, H.; Terasaki, Y.; Kurihara, Y. Immunoglobulin G4-related lung disease: Clinicoradiological and pathological features. Respirology 2013, 18, 480-487. [CrossRef]

18. Ebbo, M.; Daniel, L.; Pavic, M.; Seve, P.; Hamidou, M.; Andres, E. IgG4-related systemic disease: Features and treatment response in a french cohort: Results of a multicenter registry. Medicine (Baltimore) 2012, 91, 49-56. [CrossRef]

19. Yoo, J.; Ahn, S.S.; Jung, S.M.; Song, J.J.; Park, Y.B.; Lee, S.W. No overlap between IgG4-related disease and microscopic polyangiitis and granulomatosis with polyangiitis despite elevated serum IgG4 at diagnosis: A retrospective monocentric study. Clinical. Rheumatol. 2019, 38, 1147-1154. [CrossRef]

20. Ozawa, M.; Fujinaga, Y.; Asano, J.; Nakamura, A.; Watanabe, T.; Ito, T. Clinical features of IgG4-related periaortitis/periarteritis based on the analysis of 179 patients with IgG4-related disease: A case-control study. Arthritis Res. Ther. 2017, 19, 223. [CrossRef]

21. Perugino, C.A.; Wallace, Z.S.; Meyersohn, N.; Oliveira, G.; Stone, J.R.; Stone, J.H. Large vessel involvement by IgG4-related disease. Medicine (Baltimore) 2016, 95, e3344. [CrossRef] [PubMed]

22. Yabusaki, S.; Oyama-Manabe, N.; Manabe, O.; Hirata, K.; Kato, F.; Miyamoto, N. Characteristics of immunoglobulin G4-related aortitis/periaortitis and periarteritis on fluorodeoxyglucose positron emission tomography/computed tomography co-registered with contrast-enhanced computed tomography. EJNMMI. Res. 2017, 7, 20. [CrossRef] [PubMed]

23. Inoue, D.; Yoshida, K.; Yoneda, N.; Ozaki, K.; Matsubara, T.; Nagai, K. IgG4-related disease: Dataset of 235 consecutive patients. Medicine (Baltimore) 2015, 94, e680. [CrossRef] [PubMed]

24. Fernandez-Codina, A.; Martinez-Valle, F.; Pinilla, B.; Lopez, C.; DeTorres, I.; Solans-Laque, R. IgG4-related disease: Results from a multicenter spanish registry. Medicine (Baltimore) 2015, 94, e1275. [CrossRef]

25. Mukherjee, M.; Svenningsen, S.; Nair, P. Glucocortiosteroid subsensitivity and asthma severity. Curr. Opin. Pulm. Med. 2017, 23, 78-88. [CrossRef]

26. Ito, S.; Ko, S.B.; Morioka, M.; Imaizumi, K.; Kondo, M.; Mizuno, N. Three cases of bronchial asthma preceding IgG4-related autoimmune pancreatitis. Allergol. Int. 2012, 61, 171-174. [CrossRef]

27. Hemminki, K.; Li, X.; Sundquist, J.; Sundquist, K. Subsequent autoimmune or related disease in asthma patients: Clustering of diseases or medical care? Ann. Epidemiol. 2010, 20, 217-222. [CrossRef]

28. Wenniger, L.J.; Culver, E.L.; Beuers, U. Exposure to occupational antigens might predispose to IgG4-related disease. Hepatology 2014, 60, 1453-1454. [CrossRef]

(C) 2020 by the authors. Licensee MDPI, Basel, Switzerland. This article is an open access article distributed under the terms and conditions of the Creative Commons Attribution (CC BY) license (http://creativecommons.org/licenses/by/4.0/). 